\title{
Chemical composition and metabolic rates of gelatinous zooplankton from midwater and benthic boundary layer environments off Cape Hatteras, North Carolina, USA
}

\author{
T. G. Bailey, M. J. Youngbluth, G. P. Owen \\ Harbor Branch Oceanographic Institution, Inc., Division of Environmental, Coastal \& Ocean Sciences, 5600 U.S. 1 North, \\ Fort Pierce, Florida 34946, USA
}

\begin{abstract}
Quantitative determinations of chemical composition and oxygen consumption rates were made for 7 species of gelatinous zooplankton (ctenophores and medusae) from midwater and benthic boundary layer habitats off Cape Hatteras, North Carolina, USA. Although there were no apparent trends in chemical composition with depth of occurrence, midwater species were generally less robust, in terms of protein and lipid content, than those from benthopelagic depths. These differences in chemical compositions between midwater and benthopelagic species are probably related to factors associated with swimming behaviors required for prey capture and predator avoidance. Measurements of carbon specific metabolic rates $\left(0.59\right.$ to $\left.17.9 \mu \mathrm{lO}_{2} \mathrm{mg}^{-1} \mathrm{C} \mathrm{h}^{-1}\right)$ indicated that minimum daily rations required by mesopelagic gelatinous zooplankton can impact carbon cycling and energy transfer in deep-water ecosystems. These data are consistent with a growing inventory of metabolic measurements undertaken with submersible platforms and strongly implicate gelatinous zooplankton as ecologically important components of pelagic communities
\end{abstract}

KEY WORDS: Mesopelagic · Gelatinous · Zooplankton · Metabolism - Chemical composition

\section{INTRODUCTION}

Research during the last 2 decades has revealed that gelatinous animals are prominent constituents of the macrozooplankton in deep-sea environments (Wiebe et al. 1979, Alldredge 1984, Youngbluth et al. 1990). The broad spectrum of living and detrital particles produced and consumed by these animals qualify ctenophores, siphonophores, medusae, salps and appendicularians as important regulators of biogeochernical flux (Alldredge 1984). Gaining a more precise understanding of how these animals affect the food web structure in coastal and oceanic environments has required the development of submersible-based equipment and in situ techniques to quantify their roles in the transport and transformation of carbon in the deep sea (Youngbluth et al. 1988, Bailey et al. 1994a, Bailey et al. 1994b)

The data presented represent the first quantitative measurements of chemical compositions and meta- bolic rates for 7 species of gelatinous zooplankton and 2 species of micronekton, from midwater and benthic boundary layer regions of the water column near Cape Hatteras, North Carolina, USA. These assessments allowed estimations of minimum daily rations and predation rates.

\section{MATERIALS AND METHODS}

Individual animals were obtained at a site located $45 \mathrm{~km}$ east-southeast of Cape Hatteras, North Carolina $\left(35^{\circ} 12^{\prime} \mathrm{N}, 75^{\circ} 02^{\prime} \mathrm{W}\right.$ ) from a Johnson-Sea-Link (JSL) submersible during July 1991 (Fig. 1). Collection depths and temperatures ranged from 430 to $760 \mathrm{~m}$ and 7.2 to $4.6^{\circ} \mathrm{C}$, respectively. Metabolic rates were measured either in situ or in shipboard environmental rooms at in situ temperatures $\left(6.0 \pm 1.0^{\circ} \mathrm{C}\right)$.

Eight respirometers, mounted on the submersible, were used to gently collect the animals. The respiro- 


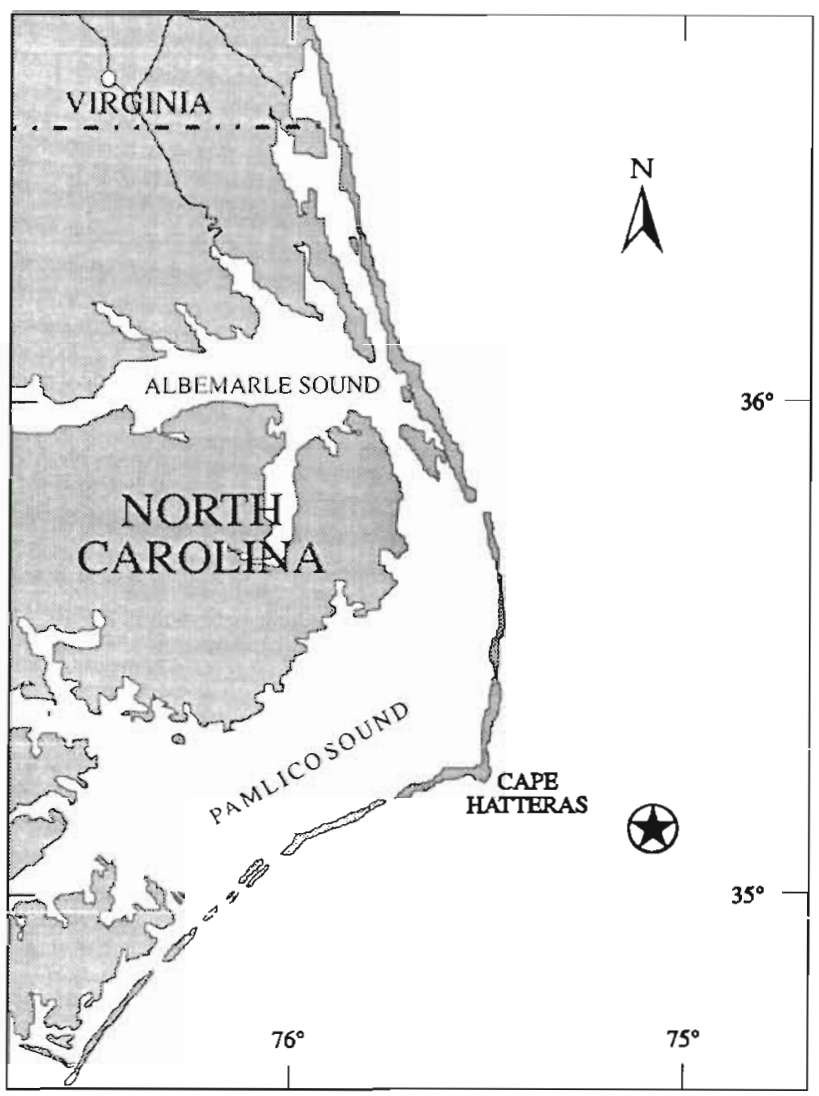

Fig. 1. Study site ( $\star$ ) off the northern coast of North Carolina USA

meters consisted of clear acrylic tubes $(1.3 \mathrm{~cm}$ thick $x$ $16.5 \mathrm{~cm}$ inner diameter) with varying lengths (either 30.5 or $15.3 \mathrm{~cm}$ ) having volumes of 6.5 or 3.3 l, respectively. These containers provide sufficient insulation to maintain animals at in situ temperatures during the 30 to $45 \mathrm{~min}$ period required for ascent to the surface, recovery of the submersible, and transfer to temperature-controlled rooms aboard ship. Additional specimens were collected with the JSL's multiple-bin suction sampler (Youngbluth 1984) for determinations of morphometric correlations and proximate chemical composition

On each of 13 dives, 6 or 7 animals were collected. The remaining respirometers were used as controls; water was collected from the same depth as the andmals. For in situ incubations, after the animals and controls had been collected, the framework holding the respirometers was attached to a moored line at a predetermined midwater depth, then detached from the submersible and left to incubate in situ for periods ranging from 20 to $25 \mathrm{~h}$. Because of inclement weather and extreme variabiluty in bottom topography, only 2 in situ experiments were conducted. Incubation depths were 570 and $600 \mathrm{~m}$. Recovery of the array was accomplished by detaching an expendable anchor from the moored line with an acoustic release. Subsurface buoys attached to the moonng brought the array to the surface where it was recovered with the support vessel.

For shipboard incubations ( $n=11$ ), once the animals and controls had been collected in the respirometers, the submersible made a slow ascent to the surface. After transfer from the submersible to a temperaturecontrolled environmental chamber, the respirometers were incubated in the dark. Once collected, none of the animals were handled or subjected to changes in temperature or water quality until the incubation was terminated. Shipboard incubation periods ranged from 6 to $25 \mathrm{~h}$ (average time $=14 \mathrm{~h}$ ).

Two types of oxygen sensors were used: (1) in situ measurements were made with Nester oxygen sensors (general purpose D.O. Probe; Leeds and Northrup Corp.); and (2) shipboard incubations were conducted using both Nester probes and Endeco pulsed oxygen electrodes (type 1128 D.O. probe; YSI). Rationale for using these electrodes, as well as response characteristics and sturring requirements of the probes, are given by Bailey et al. (1904b).

Endeco probes were installed in the respirometers prior to a dive, but were not activated until the respirometers had been placed in the environmental chamber. Because Endeco probes are profoundly affected by rapid changes in temperature and pressure, a period of 3 to $5 \mathrm{~h}$ was required for restabilization of the probes subsequent to each dive. Data obtained dunng this restabilization period were not used. Luneanty in the response of electrodes to different oxygen concentrations was established using both oxygen-saturated and deoxygenated (nitrogenstripped) water. Outputs from both Endeco and Nester sensors were recorded with solid-state data loggers.

At the conclusion of each experiment, gelatinous animals were measured (length for ctenophores and bell diameter for medusae) while still inside the respirometers. Total length for crustaceans and standard length for fishes were determıned after removing the animals from the respirometers. After removal of excess water, animals were then placed in tared jars and frozen at $-10^{\circ} \mathrm{C}$ for weight and proxumate chemistry determinations. In the shore-based laboratory, individuals were weighed to the nearest $0.01 \mathrm{~g}$ and then dried at $60^{\circ} \mathrm{C}$ to constant weight. Dried samples were homogenized for elemental and proximate chemical analyses (Youngbluth et al. 1988, Reisenbichler \& Bailey 1992, Bailey et al. 1994a).

\section{RESULTS}

Rates of oxygen consumption were recorded for 56 animals representing 9 species: 5 medusae (Aeginura 
grimaldii, Poralia rufescens, Solmissus incisus, Cyanea capillata, and Colobonema sericeum), 2 ctenophores (Bathocyroe fosteri and Agmayeria tortugensis), a sergestid shrimp (Sergestes arcticus), and a midwater eel (Serrivomer beanii). Eight of these species were collected in sufficient numbers for statistical analyses: A. grimaldii, P. rufescens, $S$. incisus, C. capillata, $C$. sericeum, $B$. fosteri, A. tortugensis, and $S$. beanii. The data for the single individual of $S$. arcticus were fortuitous in that the animal was collected unintentionally in one of the control respirometers.

\section{Vertical distributions}

Water temperature decreased steadily from ca $28^{\circ} \mathrm{C}$ just below the mixed layer to ca $5^{\circ} \mathrm{C}$ at $450 \mathrm{~m}$ (Fig. 2A). Below $450 \mathrm{~m}$ the water column was essentially isothermal $\left(4.6\right.$ to $\left.5.2^{\circ} \mathrm{C}\right)$ to the bottom $(600$ to $780 \mathrm{~m})$. With the exception of Solmissus incisus, all of the gelatinous species used in this study were found in the isothermal layer below $450 \mathrm{~m}$ (Fig. 2A). Both Sergestes arcticus and Serrivomer beanii were occasionally observed above the deep isothermal layer, but the bulk of their populations occurred below $450 \mathrm{~m}$. The relatively cold water below $450 \mathrm{~m}$, along with the occurrence of northern species, such as $S$. arcticus, suggests the presence of the southward flowing Deep Western Boundary Current (Barrett 1965) at the study site.

Bottom depth on any given dive was extremely variable due to the high-relief topography. When distributions were viewed from the perspective of proximity to the bottom, 5 of the 9 species (Aeginura grimaldii, Poralia rufescens, Colobonema sericeum, Agmayeria tortugensis, and Serrivomer beanii) were found only in the region within $200 \mathrm{~m}$ of the bottom (herein defined as the benthic boundary layer; Fig. 2B). Two other species (Cyanea capillata and Bathocyroe fosteri), although occasionally observed above the benthic boundary layer, were most abundant within the bottom $200 \mathrm{~m}$.

\section{Elemental and proximate composition}

All expressions of chemical and physiological parameters are based on measured weights (Table 1). Regressions and correlations between weight and linear measures (e.g. length and bell diameter) are also presented for comparison with literature values (Table 2).

Significant quantities of bound water are common in the tissues of gelatinous animals (Madin et al. 1981, Larson 1986, Clarke et al. 1992). Consequently, it is virtually impossible to obtain accurate measures of dry weight and water content using standard techniques
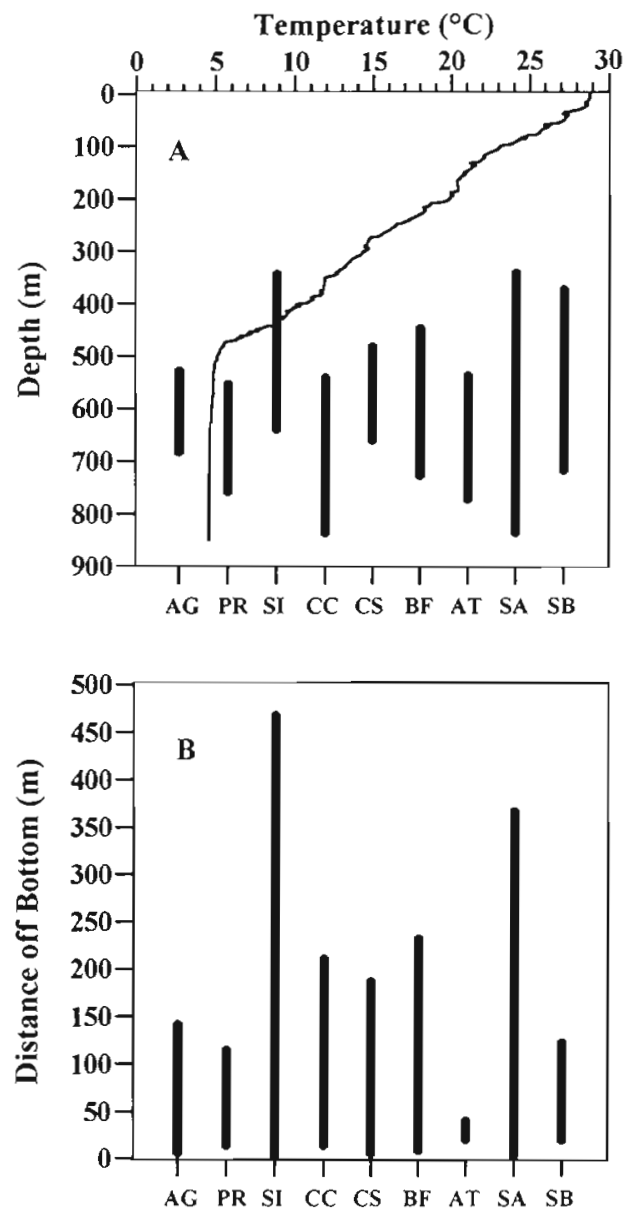

Fig. 2. Distributions of the 9 species of macrozooplankton and micronekton used for chemical composition and metabolic determinations. (A) Range of depths at which individuals were observed during submersible dives. The water column temperature profile, recorded with the JSL's CTD, is superimposed to show the relationship between species distributions and the deep isothermal layer below ca $500 \mathrm{~m}$. (B) Distance off bottom at which individuals were observed during submersible dives. Species designations are as follows: (AG) Aeginura grimaldii, (PR) Poralia rufescens, (SI) Solmissus incisus, (CC) Cyanea capillata, (CS) Colobonema sericeum, (BF) Bathocyroe fosteri, (AT) Agmayeria tortugensis, (SA) Sergestes arcticus, (SB) Serrivomer beanii

(drying at $60^{\circ} \mathrm{C}$ ). Thus, the values reported for dry weight and water content in this study probably underestimate actual values. Comparisons of data on elemental and proximate composition of marine organisms should be made on the basis of whole-body weight (wet weight; Childress 1977). However, because most literature values have been reported in terms of dry weight, we have presented our data as percentages of both wet and dry weights (Table 3). Proximate compositions expressed as a function of ashfree dry weight and carbon content can be obtained from the data and regressions provided (Tables $2 \& 3$ ). 
Table 1. Means $( \pm \mathrm{SD})$ and ranges for morphometric measurements of micronekton and macrozooplankton used in respiration experiments. Length along the longitudinal axis, for ctenophores, or bell diameter, for medusae, was determined at the conchusion of each respiration run, while the animals were in the respirometers. Standard length of Serrivomer beanii and total length of Sergestes arcticus were determined after the animals were removed from the respirometers. n: number of individuals analyzed

\begin{tabular}{|c|c|c|c|c|c|c|c|c|c|}
\hline \multirow[t]{2}{*}{ Species } & \multirow[t]{2}{*}{$\mathrm{n}$} & \multicolumn{2}{|c|}{$\begin{array}{c}\text { Length or } \\
\text { diameter }(\mathrm{mm})\end{array}$} & \multicolumn{2}{|c|}{$\begin{array}{l}\text { Wet weight } \\
\text { (q) }\end{array}$} & \multicolumn{2}{|c|}{$\begin{array}{c}\text { Dry weight } \\
\text { (g) }\end{array}$} & \multicolumn{2}{|c|}{$\begin{array}{l}\text { Carbon content } \\
\text { (mg) }\end{array}$} \\
\hline & & Mean & Range & Mean & Range & Mean & Range & Mean & Range \\
\hline \multicolumn{10}{|l|}{ Medusae } \\
\hline Aeginura grimaldii & 6 & $\begin{array}{c}14.6 \\
( \pm 1.15)\end{array}$ & $7-23$ & $\begin{array}{c}1.75 \\
( \pm 0.66)\end{array}$ & $0.85-2.56$ & $\begin{array}{c}0.08 \\
( \pm 0.03)\end{array}$ & $0.04-0.12$ & $\begin{array}{c}5.38 \\
( \pm 4.04)\end{array}$ & $2.00-12.59$ \\
\hline Poralia rufescens & 6 & $\begin{array}{c}91.4 \\
\pm 19.98)\end{array}$ & $31-240$ & $\begin{array}{c}298.25 \\
( \pm 419.10)\end{array}$ & $14.62-1079.04$ & $\begin{array}{c}12.01 \\
( \pm 16.85)\end{array}$ & $0.59-43.38$ & $\begin{array}{c}70.92 \\
( \pm 93.46)\end{array}$ & $2.60-203.89$ \\
\hline Solmissus incisus & 5 & $\begin{array}{c}58.6 \\
( \pm 6.67)\end{array}$ & $28-100$ & $\begin{array}{c}25.45 \\
( \pm 18.98)\end{array}$ & $5.58-46.30$ & $\begin{array}{c}1.04 \\
( \pm 0.79)\end{array}$ & $0.23-1.91$ & $\begin{array}{c}15.91 \\
( \pm 12.50)\end{array}$ & $2.46-28.82$ \\
\hline Cyanea capillata & 4 & $\begin{array}{c}76.0 \\
( \pm 8.76)\end{array}$ & $58-100$ & $\begin{array}{c}145.91 \\
( \pm 78.18)\end{array}$ & $57.17-238.65$ & $\begin{array}{c}6.71 \\
( \pm 3.74)\end{array}$ & $2.52-11.19$ & $\begin{array}{c}671.47 \\
( \pm 478.67)\end{array}$ & $168.59-1215.23$ \\
\hline Colobonema sericeum & 3 & $\begin{array}{c}33.3 \\
( \pm 2.19)\end{array}$ & $29-36$ & $\begin{array}{c}13.71 \\
( \pm 2.70)\end{array}$ & $10.83-16.19$ & $\begin{array}{c}0.66 \\
( \pm 0.12)\end{array}$ & $0.53-0.76$ & $\begin{array}{c}111.59 \\
( \pm 22.50)\end{array}$ & $85.75-126.89$ \\
\hline \multicolumn{10}{|l|}{ Ctenophores } \\
\hline Bathocyroe fosteri & 9 & $\begin{array}{c}41.8 \\
( \pm 3.63)\end{array}$ & $13-54$ & $\begin{array}{c}24.38 \\
( \pm 11.03)\end{array}$ & $11.56-43.77$ & $\begin{array}{c}0.98 \\
( \pm 0.45)\end{array}$ & $0.47-1.77$ & $\begin{array}{c}3.61 \\
( \pm 2.12)\end{array}$ & $1.65-7.51$ \\
\hline Agmayeria tortugensis & 5 & $\begin{array}{c}78.3 \\
( \pm 16.25)\end{array}$ & $38-122$ & $\begin{array}{c}46.34 \\
( \pm 47.58)\end{array}$ & $4.38-106.83$ & $\begin{array}{c}2.52 \\
( \pm 3.00)\end{array}$ & $0.19-6.12$ & $\begin{array}{c}491.08 \\
( \pm 650.91)\end{array}$ & $13.03-1350.70$ \\
\hline $\begin{array}{l}\text { Sergestid shrimp } \\
\text { Sergestes arcticus }\end{array}$ & 1 & 48.0 & - & 2.26 & - & 0.37 & - & 171.27 & - \\
\hline $\begin{array}{l}\text { Midwater eel } \\
\text { Serrivomer beanii }\end{array}$ & 5 & $\begin{array}{c}234.2 \\
( \pm 46.93)\end{array}$ & $132-368$ & $\begin{array}{c}4.46 \\
( \pm 6.45)\end{array}$ & $0.35-15.4$ & $\begin{array}{c}0.53 \\
( \pm 0.74)\end{array}$ & $0.04-1.78$ & $\begin{array}{c}239.00 \\
( \pm 339.13)\end{array}$ & $15.90-809.01$ \\
\hline
\end{tabular}

Among the gelatinous species, carbon and nitrogen values were highest for Colobonema sericeum and Agmayeria tortugensis and lowest for Bathocyroe fosteri and Poralia rufescens (Table 3). The elemental compositions of Sergestes arcticus and Serrivomer beanii were substantially greater than those of the gelatinous species (Table 3), and were typical of values reported for other deep-living species of crustaceans and fishes (Childress \& Nygaard 1973, 1974, Bailey \& Robison 1986, Childress et al. 1990).

Consistent with the elemental compositions, protein content for the gelatinous species ranged from relatively high values for Colobonema sericeum and $\mathrm{Ag}$ mayeria tortugensis (both nearly $1 \%$ wet $w$ t) to low values for Bathocyroe fosteri and Poralia rufescens $10.02 \%$ wet wt and $0.01 \%$ wet wt, respectively) with intermediate levels for the other 4 species (Table 3). Lipid content followed the same pattern as protein, with relatively high values for $C$. sericeum and $A$. tortugensis (ca $0.3 \%$ wet wt), low values for $B$. fosteri and $P$. rufescens $(0.01 \%$ wet wt and $0.02 \%$ wet wt, respectively), and, with the exception of Solmissus incisus $(0.01 \%$ wet wt), intermediate values for the others (Table 3 ). Carbohydrate levels were low for all species (Table 3 ). The proximate composition of Serrivomer beanii was similar to data reported for other midwater fishes (Childress \& Nygaard 1973, Bailey \& Robison 1986, Childress et al. 1990).

\section{Oxygen consumption}

Incubation times were significantly correlated ( $\mathrm{p}<0.05$; Pearson product-moment correlation) with the weight-specific amount of oxygen consumed, confirming our visual observations that the animals remained healthy during the experiments. However, the rates of oxygen consumption of 4 of the 8 species (Poralia rufescens, Solmissus, incisus, Bathocyroe fosteri, and Serrivomer beanii) were not constant over the duration of incubation. After probe stabilization, oxygen consumption rates declined during the next 3 to $6 \mathrm{~h}$ before becoming constant. Oxygen consumption rates during this initial 3 to $6 \mathrm{~h}$ period averaged 2 to 5 times higher than rates recorded afterward. In contrast, rates of decrease of oxygen for the other 4 species and in control respirometers were constant after probe stabilization. Furthermore, an initial period of declining consumption rate was not observed in either of the in situ incubations. An initial period of elevated oxygen consumption is common with this type of respirometry, particularly with active animals which require a period of acclimation to conditions after containment and ascent to the surface (Childress 1977). Although the gelatinous species examined in this study are not fast swimming animals, our data suggest that some species require a period of time to adjust to 
Table 2. Morphometric regressions and correlations. Linear regressions of log-log transformed data $\left(Y=a X^{b}\right)$ were used to derive the slopes $(b)$ and intercepts $(a)$ for the relationships between dry weight (DW) and total length/diameter (TL/D). Relationships between DW and wet weight (WW), ash-free dry weight (AFDW) and carbon content (CC) were derived from linear regressions of untransformed data ( $Y=a+b X$, where $b$ is the slope and $a$ is the intercept). The coefficient of determination $\left(r^{2}\right)$ is given for each regression. n: number of individuals analyzed

\begin{tabular}{|c|c|c|c|c|c|c|c|c|c|c|c|c|c|c|c|c|}
\hline \multirow[t]{2}{*}{ Species } & \multicolumn{4}{|c|}{$\mathrm{DW}(\mathrm{mg})=a \mid \mathrm{TL} / \mathrm{D}(\mathrm{mm})]^{b}$} & \multicolumn{4}{|c|}{$\mathrm{DW}(\mathrm{mg})=a+b[\mathrm{WW}(\mathrm{mg})]$} & \multicolumn{4}{|c|}{$\mathrm{DW}(\mathrm{mg})=a+b|\operatorname{AFDW}(\mathrm{mg})|$} & \multicolumn{4}{|c|}{$\mathrm{DW}(\mathrm{mg})=a+b[\mathrm{CC}(\mathrm{mg})]$} \\
\hline & $a$ & $b$ & $r^{2}$ & $\mathrm{n}$ & a & $b$ & $r^{2}$ & n & $a$ & $b$ & $r^{2}$ & $\mathrm{n}$ & a & $b$ & $r^{2}$ & $n$ \\
\hline Aeginura grimaldii & 5.04 & 1.12 & 0.62 & 15 & 0.50 & 0.04 & 0.99 & 15 & 13.86 & 2.86 & 0.91 & 15 & 59.58 & 6.43 & 0.40 & 15 \\
\hline Poralia rufescens & 0.10 & 2.42 & 0.96 & 12 & -22.45 & 0.04 & 0.99 & 12 & -742.89 & 4.94 & 0.93 & 10 & 3842.32 & 82.15 & 0.79 & 12 \\
\hline Solmissus incisus & 0.03 & 2.60 & 0.96 & 12 & -1.49 & 0.04 & 0.99 & 12 & 41.14 & 5.40 & 0.97 & 9 & 229.90 & 63.47 & 0.78 & 12 \\
\hline Cyanea capillata & 0.05 & 2.69 & 0.87 & 4 & -273.64 & 0.05 & 0.99 & 4 & 473.64 & 2.93 & 0.99 & 4 & 1509.46 & 7.75 & 0.98 & 4 \\
\hline Colobonema sericeum & 4.35 & 1.43 & 0.83 & 3 & 64.85 & 0.04 & 0.99 & 3 & -169.78 & 3.49 & 0.99 & 3 & 136.75 & 4.66 & 0.81 & 3 \\
\hline Bathocyroe fosteri & 10.57 & 1.13 & 0.72 & 15 & -5.40 & 0.04 & 0.99 & 15 & 178.68 & 4.46 & 0.88 & 8 & 552.71 & 60.68 & 0.48 & 15 \\
\hline Agmayeria tortugensis & 0.01 & 2.88 & 0.96 & 6 & -97.77 & 0.06 & 0.99 & 6 & 634.73 & 1.66 & 0.84 & 4 & 267.77 & 4.66 & 0.99 & 6 \\
\hline Serrivomer beanii & 0.00 & 3.39 & 0.94 & 5 & 18.64 & 0.12 & 0.99 & 5 & 1.89 & 1.17 & 0.99 & 5 & 8.19 & 2.19 & 0.99 & 5 \\
\hline
\end{tabular}

Table 3. Elemental and proximate chemical compositions as percentages of wet weight and dry weight for 9 species of macrozooplankton and micronekton. Values shown are means ( \pm SD). n: number of individuals analyzed; C: carbon; N: nitrogen; Carboh.: carbohydrate; nd: no data

\begin{tabular}{|c|c|c|c|c|c|c|c|c|c|c|c|c|c|c|}
\hline \multirow[t]{2}{*}{ Species } & \multirow[t]{2}{*}{$\mathrm{n}$} & \multicolumn{7}{|c|}{$\%$ Wet wt } & \multicolumn{6}{|c|}{$\%$ Dry wt } \\
\hline & & Water & $\mathrm{C}$ & $\mathrm{N}$ & Protein & Lipid & Carboh. & Ash & $\mathrm{C}$ & $N$ & Protein & Lipid & Carboh. & Ash \\
\hline Aeginura grimaldii & 15 & $\begin{array}{c}95.61 \\
( \pm 0.43)\end{array}$ & $\begin{array}{c}0.31 \\
( \pm 0.20)\end{array}$ & $\begin{array}{c}0.08 \\
( \pm 0.05)\end{array}$ & $\begin{array}{c}0.36 \\
( \pm 0.23)\end{array}$ & $\begin{array}{c}0.08 \\
( \pm 0.06)\end{array}$ & $\begin{array}{c}0.02 \\
( \pm 0.01)\end{array}$ & $\begin{array}{c}3.29 \\
( \pm 0.40)\end{array}$ & $\begin{array}{c}6.73 \\
( \pm 4.42)\end{array}$ & $\begin{array}{c}1.67 \\
( \pm 1.08)\end{array}$ & $\begin{array}{c}7.77 \\
( \pm 5.00)\end{array}$ & $\begin{array}{c}1.82 \\
( \pm 1.24)\end{array}$ & $\begin{array}{c}0.53 \\
( \pm 0.27)\end{array}$ & $\begin{array}{c}71.98 \\
( \pm 8.71)\end{array}$ \\
\hline Poralia rufescens & 12 & $\begin{array}{c}95.97 \\
( \pm 0.04)\end{array}$ & $\begin{array}{c}0.02 \\
( \pm 0.01)\end{array}$ & $\begin{array}{c}0.01 \\
( \pm 0.004)\end{array}$ & $\begin{array}{c}0.01 \\
( \pm 0.02)\end{array}$ & $\begin{array}{c}0.02 \\
( \pm 0.003)\end{array}$ & $\begin{array}{c}0.01 \\
( \pm 0.002)\end{array}$ & $\begin{array}{c}2.95 \\
( \pm 0.37)\end{array}$ & $\begin{array}{c}0.59 \\
( \pm 0.28)\end{array}$ & $\begin{array}{c}0.14 \\
( \pm 0.10)\end{array}$ & $\begin{array}{c}0.21 \\
( \pm 0.42)\end{array}$ & $\begin{array}{c}0.42 \\
( \pm 0.07)\end{array}$ & $\begin{array}{c}0.13 \\
( \pm 0.04)\end{array}$ & $\begin{array}{c}73.14 \\
( \pm 9.08)\end{array}$ \\
\hline Solmissus incisus & 12 & $\begin{array}{c}95.93 \\
( \pm 0.14)\end{array}$ & $\begin{array}{c}0.06 \\
( \pm 0.02)\end{array}$ & $\begin{array}{c}0.02 \\
( \pm 0.01)\end{array}$ & $\begin{array}{c}0.10 \\
( \pm 0.02)\end{array}$ & $\begin{array}{c}0.01 \\
( \pm 0.003)\end{array}$ & $\begin{array}{c}0.01 \\
( \pm 0.002)\end{array}$ & $\begin{array}{c}3.33 \\
( \pm 0.06)\end{array}$ & $\begin{array}{c}1.53 \\
( \pm 0.45)\end{array}$ & $\begin{array}{c}0.42 \\
( \pm 0.14)\end{array}$ & $\begin{array}{c}2.34 \\
( \pm 0.55)\end{array}$ & $\begin{array}{c}0.35 \\
( \pm 0.07)\end{array}$ & $\begin{array}{c}0.15 \\
( \pm 0.04)\end{array}$ & $\begin{array}{c}81.57 \\
( \pm 1.39)\end{array}$ \\
\hline Cyanea capillata & 4 & $\begin{array}{c}95.45 \\
( \pm 0.12)\end{array}$ & $\begin{array}{c}0.46 \\
( \pm 0.11)\end{array}$ & $\begin{array}{c}0.12 \\
( \pm 0.03)\end{array}$ & $\begin{array}{c}0.44 \\
( \pm 0.03)\end{array}$ & $\begin{array}{c}0.07 \\
( \pm 0.01)\end{array}$ & $\begin{array}{c}0.04 \\
( \pm 0.003)\end{array}$ & $\begin{array}{c}3.15 \\
( \pm 0.10)\end{array}$ & $\begin{array}{c}10.01 \\
( \pm 2.32)\end{array}$ & $\begin{array}{c}2.53 \\
( \pm 0.58)\end{array}$ & $\begin{array}{c}9.56 \\
( \pm 0.66)\end{array}$ & $\begin{array}{c}1.57 \\
( \pm 0.24)\end{array}$ & $\begin{array}{c}0.96 \\
( \pm 0.06)\end{array}$ & $\begin{array}{c}68.46 \\
( \pm 2.22)\end{array}$ \\
\hline Colobonema sericeum & 3 & $\begin{array}{c}95.20 \\
( \pm 0.10)\end{array}$ & $\begin{array}{c}0.81 \\
( \pm 0.07)\end{array}$ & $\begin{array}{c}0.21 \\
( \pm 0.01)\end{array}$ & $\begin{array}{c}0.84 \\
( \pm 0.15)\end{array}$ & $\begin{array}{c}0.28 \\
( \pm 0.07)\end{array}$ & $\begin{array}{c}0.06 \\
( \pm 0.003)\end{array}$ & $\begin{array}{c}3.07 \\
( \pm 0.08)\end{array}$ & $\begin{array}{c}16.91 \\
( \pm 1.47)\end{array}$ & $\begin{array}{c}4.42 \\
( \pm 0.19)\end{array}$ & $\begin{array}{c}17.39 \\
( \pm 3.03)\end{array}$ & $\begin{array}{c}5.78 \\
( \pm 1.47)\end{array}$ & $\begin{array}{c}1.17 \\
( \pm 0.07)\end{array}$ & $\begin{array}{c}63.73 \\
( \pm 1.58)\end{array}$ \\
\hline Bathocyroe fosteri & 15 & $\begin{array}{c}95.97 \\
( \pm 0.04)\end{array}$ & $\begin{array}{c}0.02 \\
( \pm 0.005)\end{array}$ & $\begin{array}{c}0.004 \\
( \pm 0.002)\end{array}$ & $\begin{array}{c}0.02 \\
( \pm 0.01)\end{array}$ & $\begin{array}{c}0.01 \\
( \pm 0.005)\end{array}$ & $\begin{array}{c}0.002 \\
( \pm 0.001)\end{array}$ & $\begin{array}{c}3.28 \\
( \pm 0.16)\end{array}$ & $\begin{array}{c}0.37 \\
( \pm 0.12)\end{array}$ & $\begin{array}{c}0.10 \\
( \pm 0.06)\end{array}$ & $\begin{array}{c}0.46 \\
( \pm 0.23)\end{array}$ & $\begin{array}{c}0.22 \\
( \pm 0.12)\end{array}$ & $\begin{array}{c}0.06 \\
( \pm 0.04)\end{array}$ & $\begin{array}{c}81.50 \\
( \pm 4.03)\end{array}$ \\
\hline Agmayeria tortugensis & 6 & $\begin{array}{c}95.16 \\
( \pm 0.73)\end{array}$ & $\begin{array}{c}1.06 \\
( \pm 0.45)\end{array}$ & $\begin{array}{c}0.14 \\
( \pm 0.07)\end{array}$ & $\begin{array}{c}0.95 \\
( \pm 0.32)\end{array}$ & $\begin{array}{c}0.29 \\
( \pm 0.25)\end{array}$ & $\begin{array}{c}0.07 \\
( \pm 0.02)\end{array}$ & $\begin{array}{c}2.62 \\
( \pm 0.99)\end{array}$ & $\begin{array}{c}19.49 \\
( \pm 8.33)\end{array}$ & $\begin{array}{c}2.53 \\
( \pm 1.23)\end{array}$ & $\begin{array}{c}17.37 \\
( \pm 5.81)\end{array}$ & $\begin{array}{c}5.34 \\
( \pm 4.63)\end{array}$ & $\begin{array}{c}1.31 \\
( \pm 0.32)\end{array}$ & $\begin{array}{c}48.12 \\
( \pm 18.25)\end{array}$ \\
\hline Sergestes arcticus & 1 & 83.63 & 7.58 & 1.35 & nd & nd & nd & nd & 46.29 & 8.27 & nd & nd & nd & nd \\
\hline Serrivomer beanii & 5 & $\begin{array}{c}87.49 \\
( \pm 1.21)\end{array}$ & $\begin{array}{c}5.36 \\
( \pm 0.31)\end{array}$ & $\begin{array}{c}1.36 \\
( \pm 0.08)\end{array}$ & $\begin{array}{c}5.64 \\
( \pm 0.76)\end{array}$ & $\begin{array}{c}1.41 \\
( \pm 0.63)\end{array}$ & $\begin{array}{c}0.19 \\
( \pm 0.02)\end{array}$ & $\begin{array}{c}2.02 \\
( \pm 0.37)\end{array}$ & $\begin{array}{c}45.09 \\
( \pm 2.59)\end{array}$ & $\begin{array}{c}11.42 \\
( \pm 0.65)\end{array}$ & $\begin{array}{c}47.45 \\
( \pm 6.42)\end{array}$ & $\begin{array}{c}11.85 \\
( \pm 5.34)\end{array}$ & $\begin{array}{c}1.63 \\
( \pm 0.18)\end{array}$ & $\begin{array}{c}16.98 \\
( \pm 3.09)\end{array}$ \\
\hline
\end{tabular}


shipboard experimental conditions. Shipboard oxygen consumption data reported in this paper were taken after this initial period of decline for the 4 affected species.

Decreases in oxygen content of water in control chambers were significant $(\mathrm{p}<0.05$; paired $t$-test). Because unfiltered water was used in the respirometers, consumption of oxygen in controls was presumed to be due to microzooplankton (e.g. ciliates) and microorganisms (e.g. bacteria). It was further assumed that similar levels of consumption by these organisms were included in experimental respirometers. Differences in the decline of oxygen content between controls and experimental respirometers were significant in every case ( $p<0.01 ; t$-test).

Weight-and carbon-specific rates of respiration for the 3 species measured in situ (Poralia rufescens, Solmissus incisus, and Bathocyroe fosteri) were significantly higher than shipboard rates $(\mathrm{p}<0.1$, $t$-test; Table 4). These differences in rates of respiration between in situ and shipboard experiments were not due to differences in response characteristics of the 2 probe types (Balley et al. 1994b).

As a function of body weight, shipboard rates of oxygen consumption for gelatinous species ranged from $0.429 \mu \mathrm{I} \mathrm{O}_{2} \mathrm{~g}^{-1}$ wet wt $\mathrm{h}^{-1}$ for Poralia rufescens to $27.254 \mu \mathrm{lO}_{2} \mathrm{~g}^{-1}$ wet wt $\mathrm{h}^{-1}$ for Aeginura grimaldii (Table 4). Based on carbon content, the range of oxygen consumption rates for the gelatinous species was $0.587 \mathrm{\mu lO}_{2} \mathrm{mg}^{-1} \mathrm{C} \mathrm{h}^{-1}$ for Colobonema sericeum to $17.890 \mu \mathrm{LO}_{2} \mathrm{mg}^{-1} \mathrm{C} \mathrm{h}^{-1}$ for Bathocyroe fosteri (Table 4). Weight-specific rates of oxygen consumption for Sergestes arcticus and Serrivomer beanii were an order of magnitude higher than those of all but 1 of the gelatinous species (A. grimaldii; Table 4). However, the carbon-specific rates for $S$, arcticus and $S$. beanii were similar to or lower than those of the gelatinous animals (Table 4).

\section{Metabolic demand}

Metabolic demand for the 5 species of medusae, expressed as carbon-specific respiration (\% body $\mathrm{C} \mathrm{d}^{-1}$, assuming a respiratory quotient of 0.8 ; Kremer 1982) ranged from 0.60 for Colobonema sericeum to 18.28 for Bathocyroe fosteri (Table 5). After accounting for differences in experimental temperatures, these values fell within the range of values reported for epipelagic medusae (Larson 1987). For the 2 ctenophore species, metabolic demands were comparable to those of epipelagic ctenophores (assuming a $Q_{10}$ value of 2.5; Kremer et al. 1986). The relatively high values for metabolic demand of Bathocyroe fosteri, Aeginura grimaldii, and Solmissus incisus were due, in large

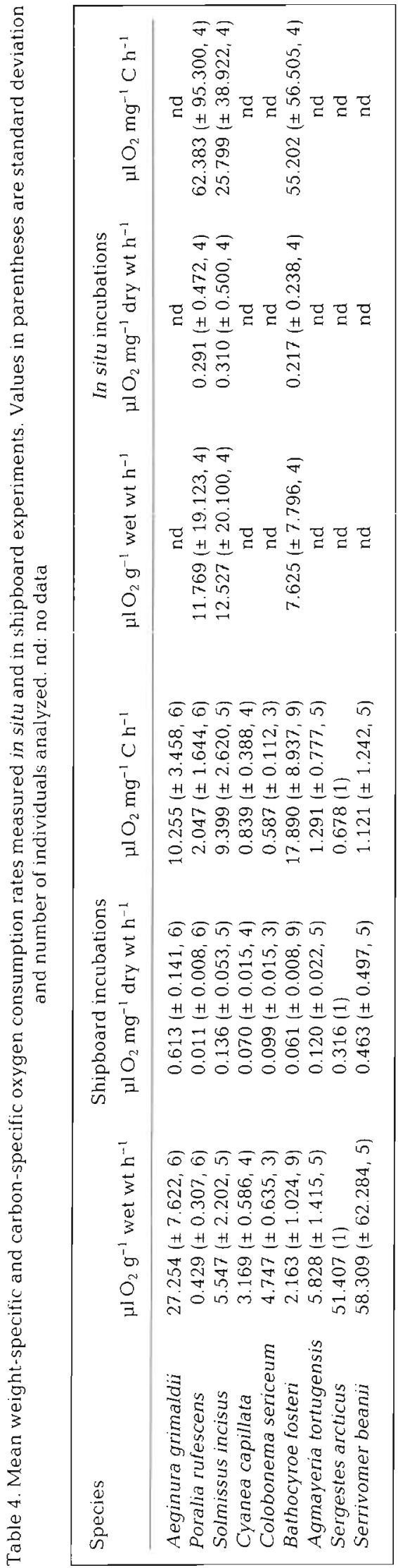


Table 5. Metabolic demand expressed as mean daily amount of carbon metabolised per individual, mean percent of total body carbon per day and daily carbon demand standardized to a body length/diameter of $40 \mathrm{~mm}$. Values were calculated using mean carbon contents and mean carbon-specific respiration rates. Daily prey requirements were calculated from values for mean daily carbon metabolised assuming an assimilation efficiency of $70 \%$ and average size deep-living prey items: a copepod, $0.08 \mathrm{mg} C$ ind $^{-1}$ (e.g. Pleuromamma xiphias) and a euphausiid, $0.22 \mathrm{mg} \mathrm{C}$ ind. $^{-1}$ (e.g. Euphausia tenera)

\begin{tabular}{|c|c|c|c|c|c|}
\hline \multirow{2}{*}{ Species } & \multicolumn{3}{|c|}{ Metabolic demand } & \multicolumn{2}{|c|}{ Daily prey requirements } \\
\hline & $\begin{array}{c}\text { Mean } \\
\left(\mathrm{mgC} \text { ind.-1 } \mathrm{d}^{-1}\right)\end{array}$ & $\left(\% \mathrm{Cd}^{-1}\right)$ & $\begin{array}{c}40 \mathrm{~mm} \\
\left(\mathrm{mg} \mathrm{C} \mathrm{d}^{-1}\right)\end{array}$ & $\begin{array}{l}\text { No. of } \\
\text { copepods }\end{array}$ & $\begin{array}{c}\text { No. of } \\
\text { euphausiids }\end{array}$ \\
\hline Aeginura grimaldii & 0.57 & 10.60 & 2.24 & 10 & 4 \\
\hline Poralia rufescens & 1.49 & 2.10 & 0.09 & 27 & 10 \\
\hline Solmissus incisus & 1.54 & 9.68 & 0.65 & 28 & 10 \\
\hline Cyanea capillata & 5.80 & 0.86 & 0.88 & 104 & 38 \\
\hline Colobonema sericeum & 0.67 & 0.60 & 0.86 & 12 & 4 \\
\hline Bathocyroe fosteri & 0.66 & 18.28 & 0.46 & 12 & 4 \\
\hline Agmayeria tortugensis & 6.52 & 1.33 & 1.07 & 116 & 42 \\
\hline Sergestes arcticus & 1.20 & 0.70 & $\sim 1.0^{\mathrm{a}}$ & 21 & 8 \\
\hline Serrivomer beanii & 2.76 & 1.15 & 1.40 & 49 & 18 \\
\hline
\end{tabular}

part, to their low levels of body carbon (Table 1). Even so, the metabolic demand of $B$. fosteri from Cape Hatteras was similar to the relatively high values reported for 1 of 2 treatments of this species from the Bahamas (Youngbluth et al, 1988). In terms of the absolute amount of carbon metabolized each day, the gelatinous animals utilized from $0.57 \mathrm{mg}$ ind.- ${ }^{-1}$ for $A$. grimaldii to $6.52 \mathrm{mg}$ ind $^{-1}$ for Agmayeria tortugensis (Table 5). When normalized to a body size of $40 \mathrm{~mm}$ (Kremer et al. 1986, Bailey et al. 1994a), the daily carbon requirements for the gelatinous species fell within the range reported for epipelagic and mesopelagic gelatinous animals (also normalized to $40 \mathrm{~mm}$; Kremer et al. 1986, Youngbluth et al. 1988) (Table 5). Values for metabolic demand based on actual body size for Sergestes arcticus and Serrivomer beanii (1.20 and $2.76 \mathrm{mg} C$ ind.$^{-1} \mathrm{~d}^{-1}$, respectively) were within the range estimated for the gelatinous species (Table 5).

\section{DISCUSSION}

\section{Chemical composition}

When compared with other deep-and shallow-living gelatinous animals (Table 6), there were no apparent trends in water content with depth of occurrence for any of the species used in our study, comparable to those observed with nongelatinous animals (e.g. Childress \& Nygaard 1973, 1974, Torres et al. 1979). Clearly, gelatinous species have adopted biochemical constitutions involving minimal levels of organic material required for their metabolic maintenance, feeding and reproductive strategies, and other physiological functions. Indeed, even the most robust gelati- nous species (e.g. Agmayeria tortugensis and Benthocodon pedunculata) have water contents comparable to the least robust species (e.g. Bathocyroe fosteri). Furthermore, water contents for gelatinous species are, without exception, substantially higher than those of nongelatinous animals (Table 6).

Data on elemental and proximate composition of gelatinous zooplankton, particularly deep-living species, are sparse. Carbon and nitrogen levels of the gelatinous animals in this study were generally similar to those of other phylogenetically related deep-living and epipelagic species (Table 6). With the exception of the benthic boundary layer cydippid, Agmayeria tortugensis, the carbon and nitrogen values for the deepliving and epipelagic ctenophores were consistently lower than those reported for deep-and shallow-living medusae. The elemental composition values for $A$. tortugensis were considerably higher than any other ctenophore and comparable to, or higher than, values reported for medusae.

Similar to carbon and nitrogen, levels of protein and lipid were generally higher for medusae than ctenophores (Table 6). Furthermore, there were no apparent trends in protein or lipid content with depth of occurrence for either ctenophores or medusae. However, several deep-living gelatinous animals are noteworthy for their robustness. The levels of protein and lipid for the medusae Colobonema sericeum were at least twice as high as any of the other 4 medusae from this study, but were comparable to those of the benthopelagic medusa Benthocodon pedunculata as well as the cydippid ctenophore Agmayeria tortugensis. These 3 species have several common characteristics which may account for the relatively high levels of organic components. First, all 3 species are restricted 
Table 6. Elemental (carbon and nitrogen) and proximate (protein, lipid and carbohydrate) compositions of gelatinous and nongelatinous macrozooplankton and micronekton. Water content is expressed as percent of wet weight. All other values are expressed as percent of dry weight. nd: no data

\begin{tabular}{|c|c|c|c|c|c|c|c|}
\hline Species & Water & Carbon & Nitrogen & Protein & Lipid & Carbohydrate & Source \\
\hline \multicolumn{8}{|c|}{ Gelatinous species } \\
\hline Bathocyroe fosteri & 95.97 & 0.37 & 0.10 & 0.46 & 0.22 & 0.06 & 1 \\
\hline B. fosteri & 96.04 & 0.44 & 0.14 & 0.64 & 0.19 & 0.05 & 2,3 \\
\hline B. fosteri & 96.19 & 0.82 & 0.20 & 0.57 & 0.38 & 0.24 & 4 \\
\hline Unident midwater lobate & 96.05 & 0.48 & 0.15 & 0.80 & 0.18 & 0.07 & 2,3 \\
\hline Bolinopsis infundibulum & nd & 2.18 & 0.45 & 1.10 & 0.20 & 1.0 & 5 \\
\hline B. infundibulum & 96.19 & 1.90 & 0.52 & 0.06 & 0.02 & nd & 6 \\
\hline B. vitrea & nd & 0.60 & 0.13 & nd & nd & nd & 7 \\
\hline Ocyropsis spp. & nd & 1.18 & 0.30 & nd & nd & nd & 7 \\
\hline Eurhamphaea vexilligera & nd & 0.88 & 0.24 & nd & nd & nd & 7 \\
\hline Mnemiopsis mccradyi & nd & 1.90 & 0.51 & nd & nd & nd & 8 \\
\hline M. leidyi & nd & 1.70 & 0.50 & nd & nd & nd & 9 \\
\hline Leucothea multicomis & nd & nd & nd & 3.70 & 2.50 & nd & 10 \\
\hline \multicolumn{8}{|c|}{ Ctenophores (cydippid, beroid, cestid) } \\
\hline Agmayeria tortugensis & 95.16 & 19.49 & 2.53 & 17.37 & 5.34 & 1.31 & 1 \\
\hline Pleurobrachia bachei & nd & 3.28 & 0.87 & nd & nd & nd & 11 \\
\hline P. pileus & 96.05 & 3.68 & 0.74 & 3.7 & 1.24 & 0.97 & 6,12 \\
\hline Beroe ovata & nd & 3.72 & 0.99 & 8.9 & 2.8 & nd & 7,10 \\
\hline B. gracilis & 96.11 & nd & nd & 0.19 & 0.16 & nd & 6 \\
\hline Cestus veneris & nd & nd & nd & 10.1 & 1.7 & nd & 10 \\
\hline \multicolumn{8}{|l|}{ Medusae } \\
\hline Aeginura grimaldii & 95.61 & 6.73 & 1.67 & 7.77 & 1.82 & 0.53 & 1 \\
\hline Poralia rufescens & 95.97 & 0.59 & 0.14 & 0.21 & 0.42 & 0.13 & 1 \\
\hline Solmissus incisus & 95.93 & 1.53 & 0.42 & 2.34 & 0.35 & 0.15 & 1 \\
\hline Colobonema sericeum & 95.20 & 16.91 & 4.42 & 17.39 & 5.78 & 1.17 & $i$ \\
\hline Cyanea capillata & 95.45 & 10.01 & 2.53 & 9.56 & 1.57 & 0.96 & 1 \\
\hline C. capillata & nd & 12.8 & 3.7 & nd & nd & nd & 13 \\
\hline Benthocodon pedunculata & 95.29 & 9.31 & 2.86 & 18.71 & 1.90 & 0.72 & 2,3 \\
\hline Rhizostoma pulmo & nd & nd & nd & 8.6 & 3.5 & nd & 10 \\
\hline Aglantha digitale & nd & 16.0 & 4.7 & nd & nd & nd & 13 \\
\hline Gonionemus vertens & nd & 13.7 & 4.1 & nd & nd & nd & 13 \\
\hline Phialidium gregarium & nd & 9.4 & 2.5 & nd & nd & nd & 13 \\
\hline Chrysaora fuscescens & nd & 7.0 & 2.0 & nd & nd & nd & 13 \\
\hline Aurelia aurita & nd & 4.3 & 1.3 & nd & nd & nd & 13 \\
\hline A aurita & 98 & 5.2 & 1.4 & 5.9 & 1.9 & 2.8 & 14 \\
\hline \multicolumn{8}{|l|}{ Other gelatinous species } \\
\hline Enypniastes eximia & 96.35 & 1.10 & 0.24 & 1.68 & 0.36 & 0.19 & 2,3 \\
\hline Pegea confoederata & nd & 7.23 & 1.02 & 7.66 & 0.96 & 0.80 & 15 \\
\hline Salpa cylindrica & nd & nd & nd & 3.47 & 0.25 & 0.49 & 15 \\
\hline S. maxima & nd & 10.76 & 2.54 & 7.96 & 0.97 & 1.42 & 15 \\
\hline S. maxima & nd & nd & nd & 3.0 & 6.2 & nd & 10 \\
\hline Pterotrachea coronata & nd & nd & nd & 5.0 & 3.0 & nd & 10 \\
\hline Sagitta hispida & 83.0 & nd & 2.2 & 53.0 & 11.1 & 2.3 & 16 \\
\hline S. elegans & nd & 39.0 & 15.1 & 54.2 & 7.8 & 1.5 & 17 \\
\hline \multicolumn{8}{|c|}{ Nongelatinous species } \\
\hline Sergestes arcticus & 83.63 & 46.29 & 8.27 & nd & nd & nd & 2 \\
\hline Sergestes sp. & nd & nd & nd & 58.0 & 29.0 & 2.0 & 18 \\
\hline S. phorcus & 77.5 & 42.76 & 10.36 & 54.13 & 20.53 & 0.62 & 19 \\
\hline S similis & 76.6 & 42.44 & 10.98 & 46.50 & 14.27 & 0.68 & 19 \\
\hline S. henseni & 75.5 & 36.86 & 10.57 & 44.45 & 5.59 & 0.41 & 20 \\
\hline S. paraseminudus & 67.0 & 37.79 & 11.00 & 43.46 & 5.42 & 0.58 & 20 \\
\hline S. pectinatus & 65.5 & nd & nd & 36.43 & 5.51 & 0.55 & 20 \\
\hline Sergia fillictum & 63.8 & 36.19 & 8.59 & 50.52 & 4.67 & 0.58 & 20 \\
\hline S. grandis & 74.5 & 37.45 & 10.28 & 43.80 & 4.98 & 0.47 & 20 \\
\hline S. robustus & 75.5 & 36.82 & 9.71 & 42.86 & 4.45 & 0.65 & 20 \\
\hline S. splendens & 71.6 & 48.43 & 13.38 & 42.15 & 5.60 & 0.56 & 20 \\
\hline Meganyctiphanes norvegica & 78.0 & nd & nd & 56.6 & 17.2 & 2.0 & 21 \\
\hline Pasiphaea emarginata & 76.7 & 45.06 & 7.68 & 33.95 & 32.49 & 0.60 & 19 \\
\hline
\end{tabular}


Table 6 (continued)

\begin{tabular}{|c|c|c|c|c|c|c|c|}
\hline Species & Water & Carbon & Nitrogen & Protein & Lipid & Carbohydrate & Source \\
\hline Systellaspis cristata & 72.8 & 50.55 & 6.51 & 31.99 & 43.75 & 0.44 & 19 \\
\hline Acanthephyra purpurea & nd & nd & nd & 60.0 & 12.0 & 2.0 & 18 \\
\hline Gennadas clavicarpus & nd & nd & nd & 62.0 & 15.0 & 3.0 & 18 \\
\hline Paracallisoma coecus & 68.2 & 51.45 & 4.50 & 15.47 & nd & nd & 19 \\
\hline Calanus finmarchicus & nd & 67.5 & 9.3 & 44.5 & 44.4 & 1.7 & 17 \\
\hline Bathycalanus princeps & 81.5 & 45.95 & 8.65 & 34.65 & 30.86 & 0.70 & 19 \\
\hline \multicolumn{8}{|l|}{ Fishes } \\
\hline Serrivomer beanii & 87.49 & 45.09 & 11.42 & 47.45 & 11.85 & 1.63 & 1 \\
\hline Avocettina sp. & 80.7 & 41.35 & 9.95 & 37.77 & 14.66 & 0.57 & 22 \\
\hline Cyema atrum & 85.1 & nd & nd & 52.48 & 29.66 & nd & 23 \\
\hline Scopelegadus miz. mizolepis & 88.0 & 37.00 & 10.25 & 48.17 & 5.75 & 0.67 & 24 \\
\hline Anoplogaster cornuta & 85.0 & 41.60 & 9.13 & 40.80 & 18.67 & 0.27 & 22 \\
\hline Stomias atriventer & 80.9 & 46.86 & 7.07 & 30.89 & 37.17 & 0.42 & 22 \\
\hline Gonostoma elongatum & 85.9 & 35.11 & 10.25 & 47.52 & 6.74 & 0.68 & 24 \\
\hline Cyclothone pallida & 81.6 & 37.07 & 10.21 & 50.92 & 6.03 & 0.54 & 24 \\
\hline Lampanyctus lineatus & 88.3 & 34.70 & 9.83 & 50.85 & 4.27 & 0.68 & 24 \\
\hline L. regalis & 86.3 & 44.74 & 8.76 & 41.39 & 21.24 & 0.51 & 22 \\
\hline Taaningichthys bathyphilus & 79.1 & nd & nd & 46.22 & 8.76 & 0.96 & 24 \\
\hline Gadus morhua ( 3 yr, mature) & 78.0 & nd & nd & 69.55 & 18.18 & nd & 25 \\
\hline \multicolumn{8}{|c|}{$\begin{array}{l}\text { Sources. 1: present study; 2: Bailey et al. (1994b); 3: Bailey (unpubl. data); 4: Youngbluth et al. (1988); 5: Bailey et al. (1994a); } \\
\text { 6: Hoeger (1983); 7: Kremer et al. (1986); 8: Reeve \& Baker (1975); 9: Kremer (1975); 10: Ceccaldi et al (1978); 11: Reeve et al. } \\
\text { (1978); 12: Schneider (1982); 13: Larson (1986); 14: Schneider (1988); 15: Madin et al. (1981); 16: Reeve et al. (1970); } \\
\text { 17: Mayzaud \& Martin (1975); 18: Raymont et al (1967); 19: Childress \& Nygaard (1974); 20: Donnelly et al. (1993); 21: Raymont } \\
\text { et al. (1971); 22: Childress \& Nygaard (1973); 23: Bailey \& Robison (1986); 24: Stickney (1987); 25: Holdway \& Beamish (1984) }\end{array}$} \\
\hline
\end{tabular}

in their distributions to the benthic boundary layer. This region of the water column is characterized by relatively high levels of available food (energy), in the form of particulate organic material, small crustaceans, and microorganisms, when compared with overlying midwater communities (Lampitt 1985, Walsh et al. 1988, Childress et al. 1989). In these regions of the water column, grazing rates and metabolic activities have been reported to be elevated in response to the higher particle concentrations (Smith 1982, Wishner \& Meise-Munns 1984). Second, all 3 species are more active swimmers than most other deep-living gelatinous counterparts. Consequently, they are more robust, in terms of protein and lipid content, than the more typical deep-living species such as Poralia rufescens and Solmissus incisus. Indeed, the proximate compositions of both deep- and shallow-living gelatinous animals appear to reflect their respective swimming capacities. For example, cydippid and beroid ctenophores (e.g. Agmayeria tortugensis, Pleurobrachia spp., and Beroe spp.) are typically more active swimmers and consequently more robust than lobate species (Table 6). Similarly, the 2 weakest swimming medusae, $P$. rufescens and $S$. incisus, have the lowest levels of protein and lipid, whereas rapid swimming species such as $C$. sericeum and $B$. pedunculata have the highest levels of organics.

Despite the implied correlation between enhanced levels of available energy and proximate compositions of gelatinous zooplankton within the benthic boundary layer, a number of recent studies have found that chemical compositions and metabolic rates of deep-sea animals do not appear to reflect food availability in their environment (Mickel \& Childress 1982, Childress \& Mickel 1985, Bailey \& Robison 1986, Childress et al. 1990). The fact that specimens of the deep-living ctenophore Bathocyroe fosteri from the highly productive study site off Cape Hatteras were not markedly more 'robust' than those from the low productivity region of the Bahamas (Youngbluth et al. 1988, Bailey et al. 1994b) argues against the theory that, at least with regard to $B$. fosteri, food availability is a major factor responsible for determining chemical composition. On the other hand, the higher levels of organic components found in the benthopelagic species, Agmayeria tortugensis and Colobonema sericeum, might be related to elevated abundance of prey near the bottom (Smith 1982, Wishner \& Meise-Munns 1984). These animals may be able to metabolically afford to support more robust bodies in exchange for enhanced locomotory abilities and thus increased prey capture probability (Mills 1981, Madin 1988). Likewise, enhanced levels of available food in the benthic boundary layer may support larger numbers of predators on gelatinous species. Consequently, benthic boundary layer gelatinous animals may require strong swimming capabilities in order to escape predation (Madin 1988). The predators of deep-living gelatinous 
animals have not as yet been identified. However, because of the enriched nature of the benthic boundary layer, this region must harbor epibenthic and demersal crustaceans and fishes which prey on gelatinous species (Auster et al. 1989). These predators may not venture very far up into the water column and thus gelatinous animals living in the overlying midwater communities may not require escape capabilities similar to benthic boundary layer species.

Despite the relatively high levels of organic components in benthic boundary layer gelatinous animals, they, along with most other gelatinous species, contain low levels of organic components when compared with nongelatinous animals (Table 6). The very low organic content of most midwater gelatinous species potentially confers a number of energy related selective advantages. Principal among these is that maximum growth rates can be achieved with minimum inputs of organic material (Childress \& Nygaard 1973, Childress et al. 1980, Larson 1986). The advantages of large size coupled with low organic content are increases in prey size range, enhanced prey contact probabilities by increasing encounter rauius GGeritisen \& Shickier 1977. Madin 1988), predator deterrence, and possibly a more rapid attainment of reproductive size. In short, large sizes can be supported without the costs of maintaining large amounts of metabolically active structural components.

\section{Metabolic rates}

The observed differences in metabolic rates between in situ and shipboard experiments (Table 4) are consistent with those reported for several other gelatinous species from midwater and benthic boundary regions of the water column (Bailey et al. 1994b) (Table 7). Based on these previous results, we have concluded that the observed disparity reflects a loss of motor activity due to decompression in those individuals measured on board ship (Bailey et al. 1994b). However, not all deep-living gelatinous animals are similarly affected by changes in pressure. For example, several deep-living species of chaetognaths and medusae showed no effects of decompression on rates of oxygen consumption (Childress \& Thuesen 1993). At the present time, it is unknown whether the metabolic rates of the 5 species that were not measured in situ were affected by pressure. The fact that one of the species used in this study, the medusae Cyanea capillata, has been reported at depths ranging from the epipelagic (Larson 1986) to mesopelagic (this study) suggests that either this animal has the capacity to modulate its metabolic processes in response to differences in pressure (long-term adaptation) or that ani- mals from the respective studies represent phenotypic variants from different oceanic ecosystems. Until the uncertainties regarding responses to pressure are resolved, we have assumed that shipboard rates of oxygen consumption reported for all the species in this study are conservative estimates of actual in situ rates.

The similarity of our rates of oxygen consumption with published rates for both mesopelagic and epipelagic species support the theory that, after accounting for differences in temperature and pressure, the metabolic rates of deep-living gelatinous zooplankton are not markedly different from those of epipelagic species (cf. Childress \& Thuesen 1992). The absence of a trend for a decrease in metabolic rates as a function of depth of occurrence suggests that deep-living gelatinous zooplankton may contribute proportionally more to carbon cycling in deep-sea communities than would be the case if there was a reduction in metabolic rate with depth of occurrence similar to that seen with crustaceans and fishes (e.g. Childress 1975, Torres et al. 1979). Indeed, the roles of gelatinous zooplankton as major contributors to carbon cycling and flux could poientially be significant in situations where they are among the numerically dominant macrofaunal elements in deep-sea communities (e.g. Smith 1982, Childress et al. 1989, Bailey et al. 1994b). Regardless of the relative abundances of gelatinous and nongelatinous macrozooplankton and micronekton within deep-sea communities, the contributions of gelatinous animals to metabolic carbon utilization is potentially significant. For example, while the weight-specific metabolic rates of the deep-living gelatinous species are, for the most part, lower than those of most midwater crustaceans, they are quite similar to the rates measured for many midwater fish species, and the carbon-specific rates of oxygen consumption of the gelatinous species in this study were substantially higher than those of most nongelatinous animals (Table 7).

\section{Prey requirements}

Inputs of organic carbon to the macrozooplankton/micronekton community come from 3 sources: particulate organic carbon (detritus), bacterioplankton, and microzooplankton (Smith 1992). Although dietary analyses have not been conducted with the deepliving gelatinous species used in this study, it is assumed that all are carnivores which feed primarily on zooplankton (e.g. copepods) and micronekton (e.g. euphausiids, shrimps and small fishes). Under steady state conditions, the combined inputs of carbon should equal the respiration (metabolic demand). Calculations based on an average metabolic demand ( $\%$ body $\mathrm{C}$ $\mathrm{d}^{-1}$; Table 5) and standardized body size $(40 \mathrm{~mm}$; 
Table 7. Comparison of mean oxygen consumption values for gelatinous and nongelatinous zooplankton and micronekton. Mes/Epi: normal depth of occurrence, mesopelagic or epipelagic. $\mathrm{n}$ : number of individuals analyzed. Temperatures are those at which incubations were conducted

\begin{tabular}{|c|c|c|c|c|c|c|c|}
\hline Species & Mes/Epi & $\mathrm{n}$ & $\begin{array}{l}\text { Temp. } \\
\left({ }^{\circ} \mathrm{C}\right)\end{array}$ & $\begin{array}{c}\text { Oxygen } \\
g^{-1} \text { wet wt }\end{array}$ & $\begin{array}{l}\text { onsumption ( } \mu \\
\mathrm{mg}^{-1} \text { dry wt }\end{array}$ & $\begin{array}{l}\left.\mathrm{O}_{2} \mathrm{~h}^{-1}\right) \\
\mathrm{mg}^{-1} \mathrm{C}\end{array}$ & Source \\
\hline \multicolumn{8}{|c|}{ Gelatinous species } \\
\hline Bathocyroe fosteri & Mes & 9 & 6 & 2.163 & 0.061 & 17.890 & 1 \\
\hline B. fosteri" & Mes & 24 & 8 & 3.057 & 0.076 & 19.157 & 2 \\
\hline B. fosteri & Mes & 3 & 8 & 0.456 & 0.032 & 6.601 & 2 \\
\hline B. fosteri & Mes & 49 & $9-12$ & 1.596 & 0.042 & 5.122 & 3 \\
\hline $\mathrm{UC}-\mathrm{I}^{\mathrm{d}}$ & Mes & 11 & 8 & 0.629 & 0.015 & 3.373 & 1 \\
\hline UC-I & Mes & 5 & 8 & 0.191 & 0.005 & 1.080 & 1 \\
\hline Ocyropsis sp. & Mes & 6 & $9-12$ & 4.787 & 0.126 & 6.300 & 3 \\
\hline Agmayeria tortugensis & Mes & 5 & 6 & 5.828 & 0.120 & 1.291 & 1 \\
\hline A. tortugensis a & Mes & 1 & 8 & 2.264 & 0.047 & 0.673 & 2 \\
\hline Bolinopsis infundibulum & Mes & 10 & $5-6$ & 2.052 & 0.054 & 2.477 & 4 \\
\hline B. infundibulum & Epi & 8 & 8 & 1.254 & 0.033 & 1.740 & 5 \\
\hline B. vitrea & Epi & 55 & 25 & 2.660 & 0.070 & 11.670 & 6 \\
\hline Ocyropsis maculata & Epi & 3 & 25 & 4.800 & 0.012 & 0.529 & 6 \\
\hline Eurhamphaea vexilligera & Epi & 47 & $25-29$ & 2.520 & 0.063 & 7.160 & 7 \\
\hline Mnemiopsis mccradyi & Epi & 22 & 21 & 3.332 & 0.098 & 5.160 & 8 \\
\hline M. leidyi & Epi & 19 & 10 & 2.380 & 0.070 & 4.120 & 9 \\
\hline M. leidyi & Epi & 21 & 25 & 7.854 & 0.231 & 13.590 & 9 \\
\hline Beroe ovata & Epi & 22 & 25 & 10.920 & 0.273 & 7.340 & 6 \\
\hline \multicolumn{8}{|l|}{ Medusae } \\
\hline Aeginura grimaldii & Mes & 6 & 6 & 27.254 & 0.613 & 10.255 & 1 \\
\hline Poralia rufescens & Mes & 6 & 6 & 0.429 & 0.011 & 2.047 & 1 \\
\hline P. rufescens ${ }^{\circ}$ & Mes & 2 & 3 & 6 & 0.160 & 27.120 & 10 \\
\hline Solmissus incisus & Mes & 5 & 6 & 5.547 & 0.136 & 9.399 & 1 \\
\hline Solmissus $\mathrm{sp}^{\mathrm{a}}$ & Mes & 4 & 8 & 4.502 & 0.113 & 7.870 & 2 \\
\hline Cyanea capillata & Mes & 4 & 6 & 3.169 & 0.070 & 0.839 & 1 \\
\hline C. capillata & Epi & 16 & 10 & 20.2 & 0.480 & 3.750 & 12 \\
\hline Colobonema sericeum & Mes & 3 & 6 & 4.747 & 0.099 & 0.587 & 1 \\
\hline Benthocodon pedunculata & Mes & 5 & 8 & 26.639 & 0.569 & 6.928 & 2 \\
\hline B. pedunculata & Mes & 9 & 8 & 8.461 & 0.161 & 1.818 & 2 \\
\hline Crossota rufobrunnea & Mes & 12 & 5 & 3.6 & 0.072 & 0.900 & 11 \\
\hline Aegina citrea & Mes & 8 & 5 & 2.8 & 0.056 & 0.700 & 11 \\
\hline Aequorea victoria & Epi & 45 & 10 & 3.9 & 0.110 & 1.100 & 12 \\
\hline Aglantha digitale & Epi & 22 & 10 & 43.7 & 0.930 & 5.810 & 12 \\
\hline Eperetmus typus & Epi & 11 & 10 & 10.0 & 0.250 & 2.910 & 12 \\
\hline Eutonina indicans & Epi & 25 & 10 & 10.6 & 0.280 & 3.150 & 12 \\
\hline Gonionemus vertens & Epi & 12 & 10 & 26.7 & 0.580 & 4.230 & 12 \\
\hline Mitrocoma cellularia & Epi & 32 & 10 & 3.2 & 0.090 & 3.210 & 12 \\
\hline Phialidium gregarium & Epi & 24 & 10 & 10.1 & 0.260 & 2.770 & 12 \\
\hline Sarsia princeps & Epi & 8 & 10 & 6.1 & 0.160 & 2.390 & 12 \\
\hline Stomotoca atra & Epi & 14 & 10 & 11.2 & 0.260 & 2.710 & 12 \\
\hline Aurelia aurita & Epi & 18 & 10 & 5.3 & 0.140 & 3.260 & 12 \\
\hline \multicolumn{8}{|c|}{ Nongelatinous species } \\
\hline Sergestes arcticus & Mes & 1 & 6 & 51.407 & 0.316 & 0.678 & 1 \\
\hline S. ammatus & Mes & 3 & 7 & 85 & 0.300 & 0.750 & 13 \\
\hline S. corniculum & Mes & 3 & 7 & 90 & 0.292 & 0.730 & 13 \\
\hline Sergia grandis & Mes & 3 & 14 & 159 & 0.568 & 1.520 & 13 \\
\hline Thysanopoda monocantha & Mes & 7 & 7 & 86 & 0.349 & $0.873^{b}$ & 13 \\
\hline Gnathophausia ingens & Mes & 41 & 5.5 & 54.4 & 0.199 & 0.404 & 14 \\
\hline Boreomysis californica & Mes & 6 & 5.5 & 29.4 & 0.169 & 0.389 & 14 \\
\hline Acanthephyra curtirostris & Mes & 9 & 5.5 & 36.3 & 0.151 & 0.351 & 14 \\
\hline Systellaspis cristata & Mes & 4 & 5.5 & 32.9 & 0.121 & 0.239 & 14 \\
\hline Hymenodora frontalis & Mes & 4 & 5.5 & 23.3 & 0.064 & 0.127 & 14 \\
\hline Pasiphaea emarginata & Mes & 6 & 5.5 & 20.6 & 0.088 & 0.195 & 14 \\
\hline Gigantocypris agassizii & Mes & 2 & 4 & 1.5 & 0.033 & 0.311 & 14 \\
\hline Bathycalanus bradyi & Mes & 5 & 4 & 39.1 & 0.139 & $0.331^{\mathrm{b}}$ & 14 \\
\hline
\end{tabular}


Table 7 (continued)

\begin{tabular}{|c|c|c|c|c|c|c|c|}
\hline \multirow[t]{2}{*}{ Species } & \multirow[t]{2}{*}{ Mes/Epi } & \multirow[t]{2}{*}{$\mathrm{n}$} & \multirow{2}{*}{$\begin{array}{l}\text { Temp. } \\
\left({ }^{\circ} \mathrm{C}\right)\end{array}$} & \multicolumn{3}{|c|}{ Oxygen consumption $\left(\mu \mathrm{O}_{2} \mathrm{~h}^{-1}\right)$} & \multirow[t]{2}{*}{ Source } \\
\hline & & & & $g^{-1}$ wet wt & $\mathrm{mg}^{-1}$ dry wt & $\mathrm{mg}^{-1} \mathrm{C}$ & \\
\hline \multicolumn{8}{|l|}{ Fishes } \\
\hline Serrivomer beanii & Mes & 5 & 6 & 58.309 & 0.463 & 1.121 & 1 \\
\hline Coryphaenoides acrolepis ${ }^{\mathrm{d}}$ & Mes & 1 & 3.5 & 2.4 & 0.012 & $0.030^{\mathrm{b}}$ & 15 \\
\hline C. armatus ${ }^{a}$ & Mes & 3 & 3.0 & 3.2 & 0.016 & $0.040^{b}$ & 16 \\
\hline Eptatretus deani ${ }^{\text {a }}$ & Mes & 1 & 3.5 & 2.2 & 0.011 & $0.028^{\mathrm{b}}$ & 15 \\
\hline Sebastolobus altivelis (juv) ${ }^{\mathrm{d}}$ & Mes & 2 & 5.7 & 30.5 & 0.153 & $0.383^{\mathrm{b}}$ & 17 \\
\hline S. altivelis (adult) ${ }^{2}$ & Mes & 4 & 5.7 & 2.8 & 0.014 & $0.035^{b}$ & 17 \\
\hline Cyclothone acclinidens ${ }^{a}$ & Mes & 3 & 3 & 25 & 0.125 & $0.287^{b}$ & 18 \\
\hline Gonostoma elongatum & Mes & 7 & 7 & 39.0 & 0.330 & $1.300^{b}$ & 13 \\
\hline Melanostigma pammelas & Mes & 2 & 5.5 & 16.1 & 0.111 & $0.124^{b}$ & 14 \\
\hline Nectoliparis pelagicus & Mes & 3 & 5.5 & 42.7 & 0.214 & $0.534^{\mathrm{b}}$ & 14 \\
\hline Bajacalifornia burragei & Mes & 3 & 5 & 5 & 0.045 & $0.113^{b}$ & 19 \\
\hline Bathylagus milleri & Mes & 3 & 5 & 11 & 0.085 & $0.213^{b}$ & 19 \\
\hline Melamphaes acanthomus & Mes & 4 & 5 & 12 & 0.096 & $0.256^{\mathrm{b}}$ & 19 \\
\hline Poromitra crassiceps & Mes & 2 & 5 & 11 & 0.084 & $0.220^{\mathrm{b}}$ & 19 \\
\hline Melanonus zugmayeri & Mes & 4 & 5 & 17 & 0.085 & $0.213^{b}$ & 19 \\
\hline Lampanyctus regalis & Mes & 1 & 5 & 11 & 0.080 & 0.179 & 19 \\
\hline Parvilux ingens & Mes & 3 & 5 & 12 & 0.133 & $0.333^{b}$ & 19 \\
\hline Scopelengys tristis & Mes & 2 & 5 & 9 & 0.059 & 0.106 & 19 \\
\hline Oneirodes acanthias & Mes & 2 & 5 & 8 & 0.084 & 0.207 & 19 \\
\hline \multicolumn{8}{|c|}{$\begin{array}{l}\text { S Species measured in situ } \\
{ }^{b} \text { Carbon-specific value was estimated based on the assumption that carbon content was equal to } 8 \text { to } 10 \% \text { of the wet weight }\end{array}$} \\
\hline \multicolumn{8}{|c|}{$\begin{array}{l}\text { Sources. 1: present study; 2: Bailey et al. (1994b); 3: Youngbluth et al. (1988); 4: Balley et al. (1994a); S: Gylienberg \& Greve } \\
\text { (1979); 6: Kremer et al. (1986); 7: Biggs (1977); 8: Kremer (1982); 9: Kremer (1977); 10: Smith (1982); } 11 \text {. Childress \& Thuesen } \\
\text { (1993); 12: Larson (1987); 13: Donnelly \& Torres (1988); 14: Childress (1975); 15: Smith \& Hessler (1974); 16: Smith (1978); } \\
\text { 17: Smith \& Brown (1983); 18: Smith \& Laver }(1981) ; 19: \text { Torres et al. (1979) }\end{array}$} \\
\hline
\end{tabular}

Kremer et al. 1986, Youngbluth et al. 1988) indicated that the daily maintenance ration from the 7 species ranged from $0.09 \mathrm{mg} \mathrm{C}$ ind.$^{-1} \mathrm{~d}^{-1}$ for Poralia rufescens to $2.24 \mathrm{mgC}_{\text {ind }}{ }^{-1} \mathrm{~d}^{-1}$ for Aeginura grimaldii. Daily carbon ration for several species of epipelagic and mesopelagic ctenophores varied from 0.15 to 1.50 $\mathrm{mgC}$ ind.$^{-1} \mathrm{~d}^{-1}$ (values standardized to a length of $40 \mathrm{~mm}$; Kremer et al. 1986). In terms of actual prey required, assuming a conservative assimilation efficiency of $70 \%$ (Reeve et al. 1978) at steady state (i.e. no growth or reproduction), the daily maintenance ration for an average size Cyanea capillata could be supplied by 104 midwater copepods (e.g. ca $0.08 \mathrm{mg} \mathrm{C}$ ind. ${ }^{-1}$ for Metridia lucens or Pleuromamma xiphias; Omori 1969, Ikeda 1974, respectively) or 38 euphausiids (e.g. ca

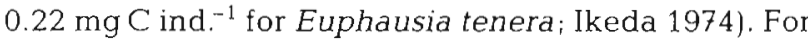
the benthic boundary layer ctenophore, Agmayeria tortugensis, the daily maintenance ration could be supplied by 116 copepods or 42 euphausiids. These requirements for $C$. capillata and $A$. tortugensis are 3 to 12 times higher than for any of the other 6 gelatinous species (Table 5). The disparity between maintenance rations for $C$. capillata and $A$. tortugensis and the other gelatinous species is primarily due to the high carbon contents coupled with low to moderate metabolic rates of both species (Tables $1 \& 4$ ). These data suggest that, when abundant, deep-living gelati- nous species have the potential to significantly impact populations of smaller zooplankton prey (e.g. copepods and euphausiids).

Prey requirements for the 2 nongelatinous species were similar to those of the gelatinous animals (Table 5). Assuming that (1) the average carbon content for Sergestes arcticus is similar to that of the individual used in our study ( $170 \mathrm{mg} \mathrm{C}$ ind.-1 $^{-1}$ ), (2) $25 \%$ of the prey carbon is metabolically unavailable (e.g. chitin), and (3) assimilation efficiency for Serrivomer beanii is $70 \%$, a single $S$. arcticus could supply the minimum carbon requirements for an average size $S$, beanii, which feeds primarily on large shrimps and euphausiids (Beebe \& Crane 1936), for a period of ca $30 \mathrm{~d}$. Clearly, this calculated estimate is extremely conservative. Although the observed metabolic rates for $S$. beanil were similar to those of other midwater fishes (Table 7), it is possible that effects of pressure and/or containment resulted in a decrease in actual in situ metabolic rates. Also, while the minimum carbon requirements for $S$. beanii may be relatively low, other physiological requirements, such as reproduction and growth, may be relatively high in this fish species. Although we lack empirical data, our observations of large numbers of both $S$. arcticus and $S$. beanii, as well as other crustacean predators (e.g. nemichthid eels), lead to the intuitive suggestion that predation rates on $S$, arcticus at our study site were prob- 
ably substantially higher than those based on metabolic demand. Thus, the co-occurrence of large populations of sergestid and euphausiid shrimps with high densities of crustacean predators was probably not coincidental. Further research, including determinations of in situ metabolic rates and feeding strategies, is needed to resolve the uncertainties regarding the roles of midwater fishes and crustaceans in carbon cycling in deep water ecosystems.

\section{Carbon transport}

Carbon transport to the sea floor off Cape Hatteras has been estimated at ca $190 \mathrm{mg} \mathrm{C} \mathrm{m}^{-2} \mathrm{~d}^{-1}$ (Schaff et al. 1992). This relatively high rate of carbon flow has been attributed to both physical and geophysical processes, including Gulf Stream-induced upwelling, the confluence of currents focused by bottom topography, and lateral inputs resulting from mass wasting processes (Schaff et al. 1992). The large input of carbon to the benthos apparently supports a significantly higher abundance and biomass of both microbes and macrofauna than adjacent areas (Schaff et al. 1992). Included in this macrofaunal assemblage are significant numbers of gelatinous macrozooplankton. Our results suggest that the metabolic processes and potential predatory impact of these gelatinous animals could be important to carbon cycling and energy transfer and transformation. However, until data on metabolic rates are combined with quantitative estimates of the distribution and abundance of both gelatinous and nongelatinous species within the midwater and benthic boundary layer ecosystems are made, assessments of carbon flow through the gelatinous component of deep-sea macrofaunal assemblages will be unreliable.

Acknowledgements. We are grateful to the captain and crews of the RV 'Edwin Link' and Johnson-Sea-Link submersible for their assistance at sea. This work constitutes Contribution No. 1079 of the Harbor Branch Oceanographic Institution, and was supported by a grant from NOAA's National Undersea Research Center, University of North Carolina at Wilmington.

\section{LITERATURE CITED}

Alldredge A.L (1984) The quantitative significance of gelatinous zooplankton as pelagic consumers. In: Fasham MJR (ed) Flows of energy and materials in marine ecosystems: theory and practice. Plenum Press, New York, p $407-433$

Auster PJ, DeGoursey RE, LaRosa SC (1989) Observations of the interactions of gelatinous zooplankton in a nearshore environment. In: Lang MA, Jaap WC (eds) Proceedings of the American Academy of Underwater Sciences, Ninth Annual Scientific Diving Symposium. American Academy of Underwater Sciences, Costa Mesa, CA, p 1-8
Bailey TG, Robison BH (1986) Food availability as a selective factor on the chemical compositions of midwater fishes in the eastern North Pacific. Mar Biol 91:131-141

Bailey TG, Torres JJ, Youngbluth MJ, Owen GP (1994b) Effect of decompression on mesopelagic gelatinous zooplankton: a comparison of in situ and shipboard measurements of metabolism. Mar Ecol Prog Ser 113:13-27

Bailey TG, Youngbluth MJ. Owen GP (1994a) Chemical composition and oxygen consumption rates of the ctenophore Bolinopsis infundibulum from the Gulf of Maine. J Plankton Res 16:673-689

Barrett JR (1965) Subsurface currents off Cape Hatteras. Deep Sea Res 12:173-184

Beebe W, Crane J (1936) Deep sea fishes of the Bermuda Oceanographic Expeditions. Family Serrivomeridae. Zoologica 20:53-102

Biggs DC (1977) Respiration and ammonium excretion by open ocean gelatinous zooplankton. Limnol Oceanogr 22: $108-118$

Ceccaldi HJ, Kanazawa A, Teshima S (1978) Chemical composition of some Mediterranean macroplanktonic organisms: 1 - Proximate analysis. Tethys 8:295-298

Childress JJ (1975) Respiratory rate of midwater crustaceans as a function of depth of occurrence and the relation to the oxygen minimum layer off southern California. Comp Biochem Physiol 50A:787-799

Childress JJ (1977) Physiological approaches to the biology of midwater organisms. In: Anderson NR, Zahuranec BJ (eds) Oceanic sound scattering prediction. Plenum Press, New York, p 301-324

Childress JJ, Gluck DL, Carney RS, Gowing MM (1989) Benthopelagic biomass distribution and oxygen consumption in a deep-sea benthic boundary layer dominated by gelatinous organisms. Limnol Oceanogr 34:913-930

Childress JJ, Mickel TJ (1985) Metabolic rates of animals from the hydrothermal vents and other deep-sea habitats. Biol Soc Wash Bull 6:249-260

Childress JJ, Nygaard MH (1973) The chemical composition of midwater fishes as a function of depth of occurrence off southern California. Deep Sea Res 20:1093-1109

Childress JJ, Nygaard MH (1974) Chemical composition and buoyancy of midwater crustaceans as function of depth of occurrence off southern California. Mar Biol 27: $225-238$

Childress JJ, Price MH, Favuzzi J, Cowles D (1990) Chemical composition of midwater fishes as a function of depth of occurrence off the Hawaiian Islands: food availability as a selective factor? Mar Biol 105:235-246

Childress JJ, Taylor SM, Cailliet GM, Price MH (1980) Patterns of growth, energy utilization and reproduction in some meso- and bathypelagic fishes off southern California. Mar Biol 61:27-40

Childress JJ, Thuesen EV (1992) Metabolic potential of deepsea animals: regional and global scales. In: Rowe $G$, Pariente $V$ (eds) Deep-sea food chains and the global carbon cycle. Kluwer, New York, p 217-236

Childress JJ, Thuesen EV (1993) Effects of hydrostatic pressure on metabolic rates of six species of deep-sea gelatinous zooplankton. Limnol Oceanogr 38:665-670

Clarke A, Holmes LJ, Gore DJ (1992) Proximate and elemental composition of gelatinous zooplankton from the Southern Ocean. J exp mar Biol Ecol. 155:55-68

Donnelly J, Stickney DG, Torres JJ (1993) Proximate and elemental composition and energy content of mesopelagic crustaceans from the eastern Gulf of Mexico. Mar Biol 115 $469-480$

Donnelly J, Torres JJ (1988) Oxygen consumption of mid- 
water fishes and crustaceans from the eastern Gulf of Mexico. Mar Biol 97:483-494

Gerritsen J, Strickler JR (1977) Encounter probabilities and community structure in zooplankton: a mathematical model. J Fish Res Bd Can 34.73-82

Gyllenberg G, Greve W (1979) Studies on oxygen uptake in ctenophores. Ann Zool Fennici 16:44-49

Hoeger U (1983) Biochemical composition of ctenophores. $\mathrm{J}$ exp mar Biol Ecol 72:251-261

Holdway DA, Beamish FWH (1984) Specific growth rate and proximate body composition of Atlantic cod (Gadus morhua L.). J exp mar Biol Ecol 81:147-170

Ikeda T (1974) Nutritional ecology of marine zooplankton. Mem Fac Fish Hokkaido Univ 22:1-97

Kremer P (1975) Excretion and body composition of the ctenophore Mnemiopsis leidyi (A. Agassiz): comparisons and consequences. In: Persoone G, Jaspers F (eds) Proc 10th Eur Mar Biol Symp, Vol 2. Universa Press, Wetteren, p 351-362

Kremer P (1977) Respiration and excretion by the ctenophore Mnemiopsis leidyi. Mar Biol 44:43-50

Kremer P (1982) Effect of food availability on the metabolism of the ctenophore Mnemiopsis mccradyi. Mar Biol 71 : $149-156$

Kremer P, Canino MF, Gilmer RW (1986) Metabolism of epipelagic tropical ctenophores. Mar Biol 90:403-412

Lampitt RW (1985) Evidence for the seasonal disposition of detritus to the deep-sea fivor and iis su'usequeni resusper1sion. Deep Sea Res 32:885-897

Larson RJ (1986) Water content, organic content and carbon and nitrogen composition of medusae from the northeast Pacific. J exp mar Biol Ecol 99:107-120

Larson RJ (1987) Respiration and carbon turnover rates of medusae from the NE Pacific. Comp Biochem Physiol 87 A: $93-100$

Madin LP (1988). Feeding behavior of tentaculate predators: in situ observations and a conceptual model. Bull mar Sci 43:413-429

Madin LP, Cetta CM, McAlister VL (1981) Elemental and biochemical composition of salps (Tunicata: Thaliacea) Mar Biol 63:217-226

Mayzaud P, Martin JLM (1975) Some aspects of the biochemical and mineral composition of marine plankton. J exp mar Biol Ecol 17:297-310

Mickel TJ, Childress JJ (1982) Effects of temperature, pressure and oxygen concentration on the oxygen consumption rate of the hydrothermal vent crab Bythograea thermydron (Brachyura). Physiol Zool 55:199-207

Mills CE (1981) Diversity of swimming behaviors in hydromedusae as related to feeding and utilization of space. Mar Biol 64:185-189

Omori M (1969) Weight and chemical composition of some important oceanic zooplankton in the North Pacific Ocean. Mar Biol 3:4-10

Raymont JEG, Austin J, Linford E (1967) The biochemical composition of certain oceanic zooplanktonic decapods. Deep Sea Res 14:113-115

Raymont JEG, Srinivasagam RT, Raymont JKB (1971) Biochemical studies on marine zooplankton - VIII. Further investigations on Meganyctiphanes norvegica (M. Sars). Deep Sea Res 18:1167-1178

Reeve MR, Baker LD (1975) Production of two planktonic carnivores (chaetognath and ctenophore) in South Florida inshore waters. Fish Bull US 73:238-248

Reeve MR, Raymont JEG, Raymont JKB (1970) Seasonal bio- chemical composition and energy sources of Sagitta hispida. Mar Biol 6:357-364

Reeve MR, Walter MA, Ikeda T (1978) Laboratory studies of ingestion and tood utilization in lobate and tentaculate ctenophores. Limnol Oceanogr 23:740-751

Reisenbichler KR, Bailey TG (1992) Microextraction of total lipid from mesopelagic animals. Deep Sea Res 38: $1331-1339$

Schaff T, Levin L, Blair N, DeMaster D, Pope R, Boehme S (1992) Spatial heterogeneity of benthos on the Carolina continental slope: large $(100 \mathrm{~km})$-scale variation. Mar Ecol Prog Ser 88:143-160

Schneider G (1982) Abundance and chemical composition of the ctenophore Pleurobrachia pileus in western Kiel Bight. Comm Meet Int Counc Explor Sea CM-ICES: L:15:1-8

Schneider G (1988) Chemische Zusammensetzung und Biomasseparameter der Ohrenqualle Aurelia aurita. Helgoländer Meeresunters 42:319-327

Smith KL Jr (1978) Metabolism of the abyssopelagic rattail Coryphaenoides armatus measured in situ. Nature 274 362-364

Smith KL Jr (1982) Zooplankton of a bathyl benthic boundary Iayer: in situ rates of oxygen consumption and ammonium excretion. Limnol Oceanogr 27:461-471

Smith KL Jr (1992) Benthic boundary layer communities and carbon cycling at abyssal depths in the central North Pacific. Limnol Oceanogr 27:1034-1056

Smith KL jr, Brown ivo i1983j Oxygen consumption of pelagic juveniles and demersal adults of the deep-sea fish Sebastolobus altivelis, measured at depth. Mar Biol 76: $325-332$

Smith KL Jr, Hessler RR (1974) Respiration of benthopelagic fishes: in situ measurements at 1230 meters. Science 184: $72-73$

Smith KL Jr, Laver MB (1981) Respiration of the bathypelagic fish Cyclothone acclinidens. Mar Biol 61:261-266

Stickney DG (1987) Chemical composition of mesopelagic fishes from the eastern Gulf of Mexico. Masters thesis, University of South Florida, St Petersburg

Torres JJ, Belman BW, Childress JJ (1979) Oxygen consumption rates of mid-water fishes as a function of depth of occurrence. Deep Sea Res 26:185-197

Walsh I, Fischer K, Murray D, Dymond J (1988) Evidence for resuspension of rebound particles from near-bottom sediment traps. Deep Sea Res 35:59-70

Wiebe PH, Madin LP, Haury LR, Harbison GR, Philbin LM (1979) Diel vertical migration by Salpa aspera and its potential for large-scale particulate organic matter transport to the deep-sea. Mar Biol 53:249-255

Wishner KF: Meise-Munns CJ (1984) In situ grazing rates of deep-sea benthic boundary-layer zooplankton. Mar Biol 84:65-74

Youngbluth MJ (1984) Manned submersibles and sophisticated instrumentation: tools for oceanographic research. In: Proceedings of SUBTECH '83 Symposium. Society for Underwater Technology, London, p 335-344

Youngbluth MJ, Bailey TG, Jacoby CA (1990) Biological explorations in the mid-ocean realm: food webs, particle flux, and technological advancements. In: Lin YC, Shida KK (eds) Man in the sea, Vol II. Best Publ, San Pedro, CA, p 191-208

Youngbluth MJ, Kremer P, Bailey TG, Jacoby CA (1988) Chemical composition, metabolic rates and feeding behavior of the midwater ctenophore Bathocyroe fosteri. Mar Biol 98:87-94

Manuscript first received: June 15, 1994

Revised version accepted: March 8, 1995 